\title{
Mikoriza Uygulanmış ve Uygulanmamış Domates Bitkisinde Farklı Fungusit Dozlarının Meyve Kalite Parametreleri Üzerindeki Etkilerinin Karşılaştırılması
}

\author{
Tuğba ÖZBUCAK ${ }^{* 1}$ (i), Döndü KABUL ${ }^{2}$ (i) \\ ${ }^{1}$ Ordu Üniversitesi Fen-Edebiyat Fakültesi, Moleküler Biyoloji ve Genetik Bölümü, Ordu, Türkiye \\ ${ }^{2}$ Penpe Izzet Şahin Güzel Sanatlar Lisesi, Ordu, Türkiye
}

Öz: Çalışma bitkilere önemli avantajlar sağlayan mikorizaların fungusit varlığında bitki üzerindeki etkisini belirlemek için yapılmış ekolojik temelli bir araştırmadır. Bu amaçla Arbusküler Mikorizal Fungus (Glomus fasciculatum, Glomus intraradices, Glomus mosseae) bulunan ve bulunmayan ortamlarda yetiştirilen domates (Solanum lycopersicum L.) bitkilerine uygulanan farklı fungusitin dozlarının meyve kalite parametreleri üzerindeki etkileri karşılaştııılmıştır. Pestisit dozları çiftçiye önerilen tarla dozu (D), önerilenin yarısı doz (D/2) ve önerilenin iki katı doz (Dx2) şeklinde uygulanmıştır. Meyve ağırlı̆ı̆, meyve boyu, meyve çapı ve meyve hacmi ölçüm sonuçları bütün fungusit dozlarında mikorizalılarda istatistiki açıdan önemli bulunmuştur. Bu sonuçlar mikorizanın fungusit uygulamasına rağmen meyve üzerinde olumlu etkileri olduğunu göstermektedir. Mikorizalı bitkilerin meyvelerinde fungusit kalıntısına rastlanmazken mikorizasız bitkilerin D ve Dx2 dozlarında ölçüm limitinde ve ölçüm limitinin üzerinde fungusit kalıntısına rastlanmıştır.

Anahtar Kelimeler: Antracol WP 70, Arbusküler Mikorizal Fungus (AMF), domates (Solanum lycopersicum L.), meyve özellikleri

\section{Comparision of Effects of Different Fungicide Doses on Fruit Quality Parameters in Mycorrhizal Applied and Untreated Tomato Plant}

\begin{abstract}
The study is an ecological-based study to determine the effect of mycorrhiza on the plant in the presence of fungicides, which provide important advantages to plants. For this purpose, it was compared the effects of different fungicide doses on fruit quality parameters of tomato (Solanum lycopersicum L.) plants grown in environment with and without Arbuscular Mycorrhizal Fungus (Glomus fasciculatum, Glomus intraradices, Glomus mosseae). Pesticide was applied at different doses which recommended dose to farmer (D), half of recommended dose $(D / 2)$ and two fold recommended dose ( $\left.D^{*} 2\right)$. The results of fruit weight, fruit length, fruit size and fruit volume characteristics were found statistically significant in all of the pesticide dose in mycorhizal plants. These results indicate that mycorrhiza has positive effect despite pesticide application. There was no found pesticide residue in the fruits of mycorhizal plants. However, pesticide residue above measurement limit was found in non-mycorhizal plants.
\end{abstract}

Keywords: Antracol WP 70, Arbuscular Mycorrhizal Fungus (AMF), tomato (Solanum lycopersicum L), fruit characters

\section{GiRiş}

Son yıllarda hızlı nüfus artışının getirdiği en önemli sorunlardan birisi besin ihtiyacının karşılanamamasıdır (Palta, 2010). Bu sorunu çözmenin bir yolu da tarım alanlarından üst düzeyde ürün alabilmek ve bu yöndeki çalışmaları hızlandırmaktır. Tarımda gıda üretiminde kimyasal kökenli birçok girdi kullanılmaktadır. Gübreler ve pestisitler bunların başında gelmektedir (Tiryaki ve ark., 2010; Delen ve ark., 2010; Erzurumlu ve Kara, 2014). Bu tür kimyasalların kullanımı ekosistem üzerinde sürekli ve periyodik zarara yol açmaktadır (Palta ve ark., 2016). Bilinçsiz ve denetimsiz olarak pestisit kullanılması kalıntı sorununa ve organizmaların pestisitlere karşı direnç kazanmasına neden olmaktadır (Tort ve ark., 2004). Bu da tarımda kimyasalların kullanımını azaltmaya ve alternatif çalışmalar geliştirmeye yönelik araştırmaların artmasına özellikle organik tarım, sürdürülebilir tarım gibi bir takım kavramların ortaya çıkmasına neden olmuştur (Tilak ve ark., 2005).

Mikorizalar; bitkiler ve funguslar arasındaki besin elementi döngüsünü ve verimliliğini arttıran en önemli simbiyotik ilişkilerden birisidir. Bitkilerin önemli bir kısmında mikorizal funguslarla birliktelik bulunmaktadır. Bu nedenle mikorizal ilişkiler ekolojik açıdan büyük öneme sahiptirler (Palta, 2010). Bitki-mikoriza işbirliğinin toprağın yapısını iyileştirme, bitkiyi abiyotik ve abiyotik stres faktörlerine karşı koruma ve bitkinin hayatta kalma başarısını arttırma gibi avantajları vardır (Ted, 2002; Marin ve ark., 2002; Altuntaş ve ark., 2015; Rafique and Ortaş, 2018).

Bitki büyüme ve gelişmesi üzerinde mikorizaların ve pestisitlerin etkilerini gösteren pek çok çalışma vardır (Tiryaki ve ark., 2010; Tiryaki, 2016; Altuntaş, 2015; Palta, 2016; Naomi ve Rintoul, 2016; Abdulhadi ve ark., 2017; Azimi ve ark., 2018; Rafique and Ortaş, 2018). Bununla beraber, mikoriza ile kolonize olmuş bitkilerde pestisit kullanımının meydana getirdiği etkiler ile ilgili çalışmalar daha çok pestisitin fungusun kolonizasyon miktarı, verimliliği ile besin element içerikleri üzerinedir (Marin ve

Sorumlu Yazar: tsiozbucak@hotmail.com Bu çalışma yüksek lisans tez ürünüdür ve Ordu Üniversitesi BAP birimi tarafından AR-1535 kodu ile desteklenmiştir.

Geliş Tarihi: 26 Nisan 2019

Kabul Tarihi: 11 Aralık 2019 
ark., 2002; Chhabra ve Jalali, 2013). Kontrolsüz, bilinçsiz ve aşırı kullanım sonucu artan pestisit kullanımı bitkilerde ve besin zinciri yoluyla da insan dâhil diğer canlılarda birtakım zararlara yol açmaktadır (Naomi ve Rintoul, 2016). Bu noktadan hareketle bu çalışmada bitkiye önemli avantajlar sağlayan mikorizanın pestisit muamelesine karşı da dayanıklılık sağlayabileceği hipotezi ile ihracatı sırasında kalıntı sorunları yaşanan domates bitkisi çalışılmıştır.

Bu çalışmanın amacı özetle, Arbusküler Mikorizal Fungus (Glomus fasciculatum, Glomus intraradices, Glomus mosseae) uygulanmış ve uygulanmamış ortamlarda yetiştirilen domateste Antracol WP 70 fungusitinin çiftçiye önerilen tarla dozu, önerilenin yarısı ve önerilenin iki katı dozlarının meyve kalite parametreleri üzerindeki etkilerini karşılaştırmaktır.

\section{MATERYAL VE YÖNTEM}

\section{Materyal}

Araştırmada bitkisel materyal olarak Olgun F1 (Yüksel Tohum, Antalya) domates (Solanum lycopersicon) tohumu, toprak olarak torf, perlit, toprak (2:1:1) karışımı kullanılmıştır. Kullanılan toprak Ordu Orman Işletmesi' nden temin edilmiş olup, kumlu killi tınlı toprak (\% 60 kum, \% 25 kil, \% 15 silt) özelliğindedir. Çalışmada kullanılan mikorizal funguslar ticari Symbion VAM adında, içeriğinde ağırlıklı olarak Glomus fasciculatum, Glomus intraradices, Glomus mosseae türlerinin bulunduğu preperatlardır. Symbion VAM suda çözünmez ve toz formulasyona sahiptir. Pestisit olarak ise Karadeniz Bölgesi'nde domates mildiyösü, yaprak küfü ve erken yanıklık hastalıklarında yaygın olarak kullanılan Antracol WP 70 (etkin madde Propineb \% 70) marka fungusit kullanılmıştır. Propineb, etken madde $\mathrm{C}_{5} \mathrm{H}_{8} \mathrm{~N}_{2} \mathrm{~S}_{4} \mathrm{Zn}$ kimyasal formüle ve $289.78 \mathrm{~g} / \mathrm{mol}$ molekül ağırlığı olan, karakteristik bir kokuya sahip, sarı renkte ve kristal veya toz formunda katı bir hammaddedir.

\section{Yöntem}

Domates tohumları ekilmeden önce steril edilmiştir. Tohumlar önce \% 70'lik etil alkol çözeltisinde 1 dakika bekletilip, sonra sırasıyla saf suda 1 dakika, \% 10'luk sodyum hipoklorit $(\mathrm{NaOCl})$ çözeltisinde 5 dakika tutulmuştur. Tohumlar son olarak saf su ile $10 \mathrm{kez}$ yıkanmıştır Son yıkamada tohumlar 20 dakika saf suda bekletilerek, suları filtre kâğıdından süzülmüştür (Battke ve ark. 2003). Steril edilen domates tohumlarının yarısı içerisinde Symbion VAM marka mikoriza mantarları bulunan torf, perlit, toprak karışımının olduğu plastik kaplara ekilmiştir. Ekilen tohumlar 10 saat gece, 14 saat gündüz periyodunda $23.5^{\circ} \mathrm{C}$ sıcaklık ve \% 60 nem olarak ayarlanan iklim dolabında 30 gün bırakılmışlardır. Bu süre içerisinde tohumlar gün aşırı sulanmıştır (Şekil 1). Gün aşırı sulanan tohumlar iklim dolabından çıkartıldıktan sonra dış ortamda yaklaşık 2 hafta büyümeleri sağlanmıştır (Şekil 2). 162

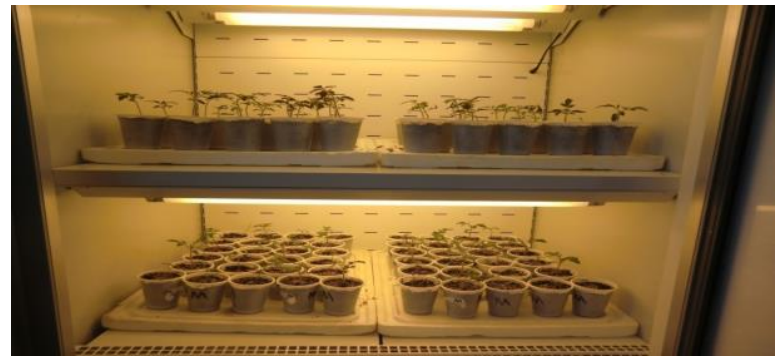

Şekil 1. İklim dolabında fidelerin büyümesi

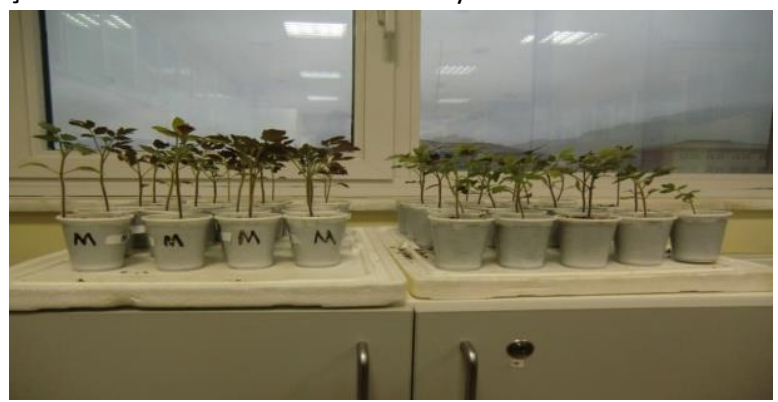

Şekil 2. İklim dolabından çıkarılan fideler

Daha sonra sağlıklı olan fideler 24 saksıya her birine iki tane olacak şekilde $20 \mathrm{~L}$ hacmindeki saksılara alınmıştır (Şekil 3). Çalışma, plastik yapılı, tek çatılı, yaklaşık $50 \mathrm{~m}^{2 \prime}$ lik bir alanda kurulan sera ortamında yürütülmüştür.

Fungusit uygulaması bitkiye bir püskürtücü yardımı ile gerekli tedbir ve önlemler alındıktan sonra püskürtme şeklinde üreticinin uygulama ve dozuna benzer şekilde fideler saksılara şaşırtıldıktan 24 gün sonra 7 gün ara ile 5 kez yapılmıştır (Şekil 4). Çalışmada bitkiye üretici firma tarafından önerilen doz (0.75 g/250 mL su), önerilen dozun yarısı $(0.375 \mathrm{~g} / 250 \mathrm{~mL} \mathrm{su})$ ve önerilen dozun iki katı

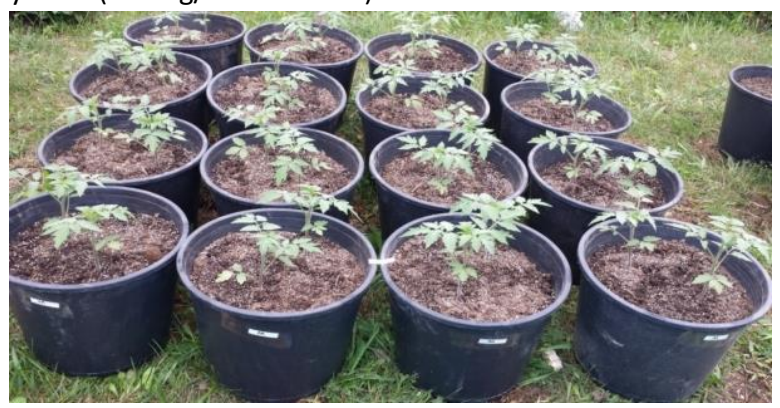

Şekil 3. Fidelerin saksılara aktarılması

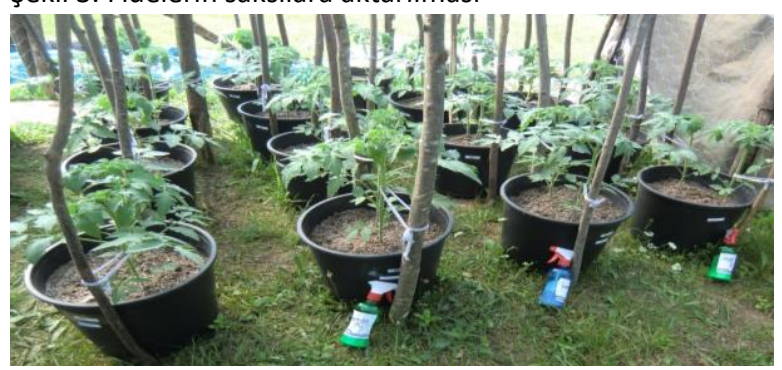

Şekil 4. Fungusit uygulama aşamasındaki fideler 
(1.5 g/250 mL su) şeklinde pestisit uygulanmıştır. Kontrol grubuna hiç pestisit uygulanmamıştır. illk çiçeklenme döneminden (Şekil 5a) sonraki hasat döneminin

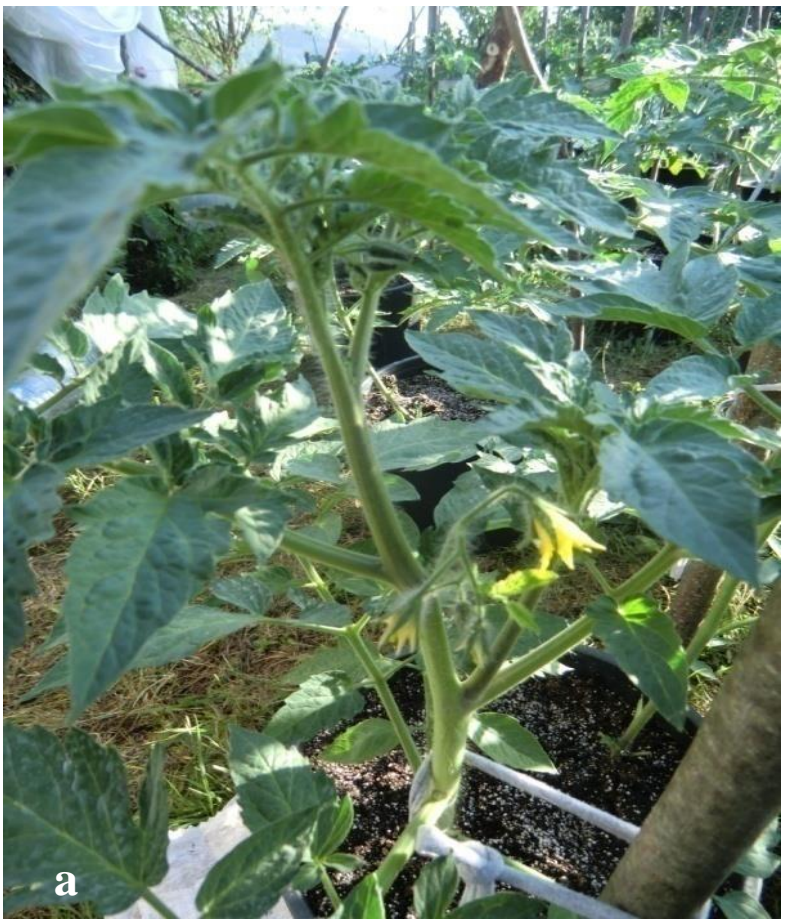

Şekil 5. a) ilk çiçeklenme dönemi, b) Hasat dönemi başlangıcı Ortalama Meyve Ağırlı̆ı̆ (g): Meyveler ayrı ayrı $\pm 0.5 \mathrm{~g}$ hassaslıktaki elektronik bir terazi yardımı ile tartılıp ortalamaları alınmıştır.

Meyve Çapı (mm): Aynı meyvelerde, ekvatoral bölgenin çapı $\pm 0.1 \mathrm{~mm}$ hassaslıktaki dijital bir kumpasla ölçülüp ortalamaları alınmıştır.

Meyve Boyu (mm): Aynı meyvelerde çiçek çukuru ile sap çukuru arasındaki bölüm $\pm 0.1 \mathrm{~mm}$ hassaslıktaki dijital bir kumpas yardımı ile ölçülüp ortalamaları alınmıştır.

Meyve Hacmi $\left(\mathrm{cm}^{3}\right)$ : Aynı meyvelerde belli seviyede su bulunan ölçekli beher içerisine koyulan meyvelerin, taşan su miktarı ölçülüp ortalaması alınmıştır.

Fungusit Kalıntı Analizleri: Pestisit kalıntı analizleri Proanaliz Laboratuar'ında (Alaşehir/Manisa) yapılmıştır. Domatesteki pestisit kalıntı analizleri için GC / MS (Agilent 5975 ve 7038 Series) cihazı kullanılmıştır.

İstatistiki Analiz: Verilerin normal dağılımı KolmogorovSmirnov testi ile kontrol edilmiştir. Grup varyanslarının homojenlik kontrolü Levene testi ile yapılmıştır. Değişkenlerin ortalama, standart hata, standart sapma, minimum ve maksimum gibi tanıtıcı istatistik değerleri hesaplanmıştır. Değişkenlerin değerlendirilmesinde iki faktörlü (mikoriza ve fungusit dozu) varyans analizi (Twoway ANOVA) kullanılmıştır. Gruplar arası farklılıklar (aynı veya farklı) Tukey çoklu karşılaştırma testi ile incelenmiş ve sonuçları harfli gösterim şeklinde ifade edilmiştir.
ÖZBUCAK T, KABUL D başlangıcında (Şekil 5b) toplanan meyve örneklerinde aşağıda belirtilen ağırlık $(\mathrm{g})$, boy $(\mathrm{mm})$, çap $(\mathrm{mm})$ ve hacim $\left(\mathrm{cm}^{3}\right)$ özellikleri incelenmiştir.

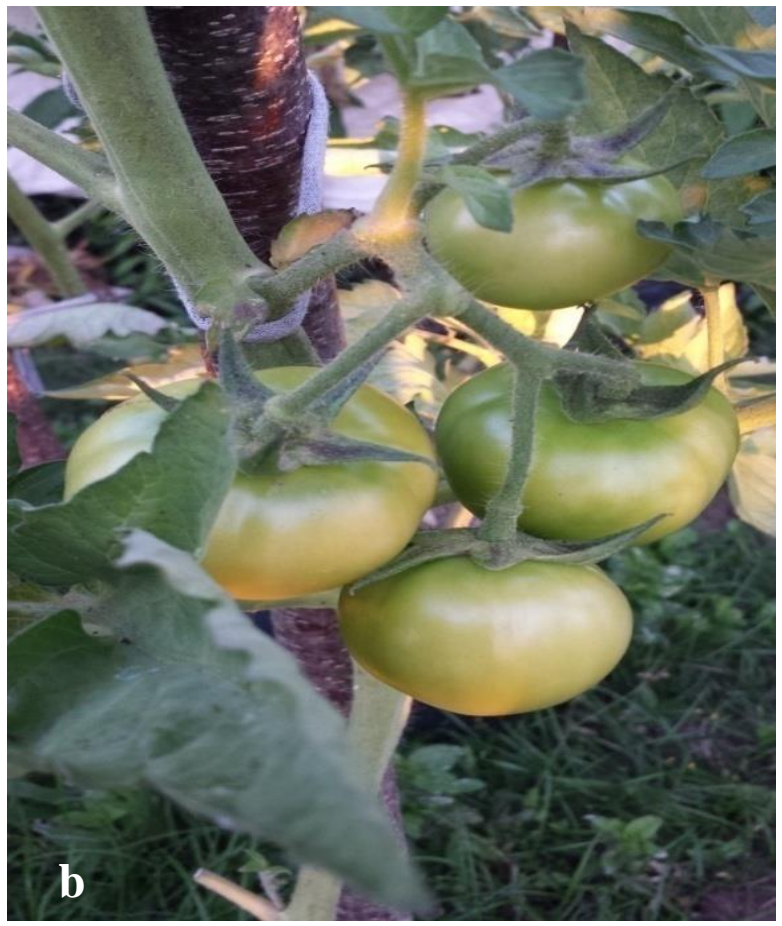

Hesaplamalarda ve yorumlamalarda \%5 önem düzeyi kullanılmıştır. Tüm hesaplamalar Minitab 17 istatistik paket programı ile yapılmıştır.

\section{BULGULAR}

Arbusküler Mikorizal Fungus (Glomus fasciculatum, Glomus intraradices, Glomus mosseae) uygulanmış ve uygulanmamış ortamlarda yetiştirilen domateste Antracol WP 70 fungusitinin çiftçiye önerilen tarla dozu, önerilenin yarısı ve önerilenin iki katı dozlarının meyve ağırlığı, meyve boyu, meyve çapı, meyve hacmi üzerindeki etkileri aşağıda verilmiştir:

\section{Meyve Ağırlığı (g)}

Çizelge 1 incelendiğinde, mikoriza*doz interaksiyonunun ve pestisit dozları arasındaki farklılığın istatistiki açıdan önemli olmadığı tespit edilmiştir $(P>0.05)$. Tukey sonuçları incelendiğinde; mikoriza varlığında elde edilen meyve ağırlığının mikoriza olmadığında elde edilen meyve ağırlığından oldukça yüksek olduğu görülmektedir $(P<0.05)$. Meyve ağırlığı kontrol grubunda, D/2, D ve Dx2 dozunda mikorizalı>mikorizasız şeklindedir.

\section{Meyve Boyu $(\mathrm{mm})$}

Meyve boyuna $(\mathrm{mm})$ ait tanıtıcı istatistik değerleri, varyans analizi ve Tukey testi sonuçları Çizelge 2'de verilmiştir. Çizelge 2'ye göre, varyans analizi sonucunda mikoriza*doz interaksiyonunun istatistik açıdan önemli olmadığı 
Çizelge 1. Meyve ağırlığına (g) ait tanıtıcı istatistik değerleri ve varyans analizi sonuçları

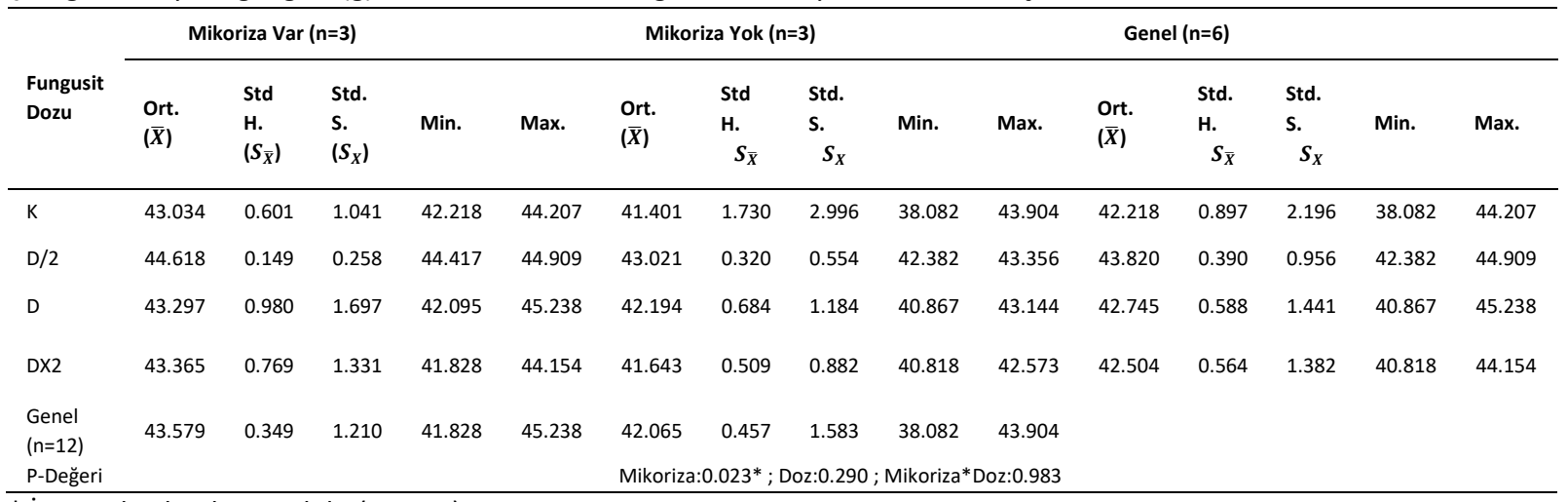

* İstatistiki olarak önemlidir $(\mathrm{P}<0.05)$

Çizelge 2. Meyve boyuna $(\mathrm{mm})$ ait tanıtıcı istatistik değerleri ve varyans analizi sonuçları

\begin{tabular}{|c|c|c|c|c|c|c|c|c|c|c|c|c|c|c|c|}
\hline \multirow[b]{2}{*}{$\begin{array}{l}\text { Fungusit } \\
\text { Dozu }\end{array}$} & \multicolumn{5}{|c|}{ Mikoriza $\operatorname{Var}(n=3)$} & \multicolumn{3}{|c|}{ Mikoriza Yok (n=3) } & \multicolumn{7}{|c|}{ Genel $(n=6)$} \\
\hline & $\begin{array}{l}\text { Ort. } \\
(\bar{X})\end{array}$ & $\begin{array}{l}\text { Std } \\
\text { H. } \\
\left(S_{\bar{X}}\right)\end{array}$ & $\begin{array}{l}\text { Std. } \\
\text { S. } \\
\left(S_{X}\right)\end{array}$ & Min. & Max. & $\begin{array}{l}\text { Ort. } \\
(\bar{X})\end{array}$ & $\begin{array}{l}\text { Std } \\
\text { H. } \\
\left(S_{\bar{X}}\right)\end{array}$ & $\begin{array}{c}\text { Std. } \\
\text { S. } \\
\left(S_{X}\right)\end{array}$ & Min. & Max. & $\begin{array}{l}\text { Ort. } \\
(\bar{X})\end{array}$ & $\begin{array}{l}\text { Std } \\
\text { H. } \\
\left(S_{\bar{X}}\right)\end{array}$ & $\begin{array}{l}\text { Std. } \\
\text { S. } \\
\left(S_{X}\right)\end{array}$ & Min. & Max. \\
\hline K & 38.460 & 0.308 & 0.533 & 37.932 & 38.998 & 37.587 & 0.179 & 0.310 & 37.287 & 37.907 & $38.023 B$ & 0.252 & 0.617 & 37.287 & 38.998 \\
\hline$D / 2$ & 39.476 & 0.839 & 1.453 & 38.603 & 41.153 & 39.078 & 0.087 & 0.151 & 38.937 & 39.237 & $39.277 \mathrm{AB}$ & 0.388 & 0.949 & 38.603 & 41.153 \\
\hline D & 40.205 & 0.205 & 0.354 & 39.857 & 40.565 & 39.007 & 0.249 & 0.431 & 38.525 & 39.355 & $39.606 \mathrm{~A}$ & 0.304 & 0.745 & 38.525 & 40.565 \\
\hline DX2 & 40.214 & 0.200 & 0.346 & 39.833 & 40.508 & 39.297 & 0.760 & 1.316 & 38.030 & 40.657 & $39.756 \mathrm{~A}$ & 0.407 & 0.997 & 38.030 & 40.657 \\
\hline $\begin{array}{l}\text { Genel } \\
(n=12)\end{array}$ & 39.589 & 0.295 & 1.021 & 37.932 & 41.153 & 38.742 & 0.269 & 0.932 & 37.287 & 40.657 & & & & & \\
\hline P-Değeri & & & & & & Mikoriza: & $15^{*} ; \mathrm{D}$ & $: 0.005^{* *}$ & Mikoriza & Doz:0.837 & & & & & \\
\hline
\end{tabular}

* İstatistiki olarak önemlidir $(\mathrm{P}<0.05)$

** İstatistiki olarak önemlidir $(\mathrm{P}<0.01)$

Ortak harfi olmayan doz ortalamaları arasındaki farklılık istatistiki olarak önemlidir $(\mathrm{P}<0.05)$

görülmektedir ( $P>0.05)$. Mikoriza olup olmaması arasında meyve boyuna etki bakımından farklılık ise istatistiki olarak önemli bulunmuştur $(\mathrm{P}<0.05)$. Aynı şekilde pestisit dozları arasındaki farklılık da istatistiki açıdan önemli bulunmuştur $(P<0.01)$. Hangi dozlar arasında farklılık olduğunun belirlenmesi amacıyla yapılan Tukey testi sonuçları incelendiğinde; mikorizalı ortamdaki meyve boyunun mikoriza olmadığında elde edilen meyve boyundan anlamlı derecede yüksek olduğu görülmektedir $(P<0.05)$. Meyve boyu kontrol grubunda, $D / 2, D$ ve $D x 2$ dozunda mikorizalı>mikorizasız şeklindedir. Ayrıca pestisit dozları arasındaki farklılık incelendiğinde; Meyve boyu D, Dx2 dozlarında kontrole göre daha yüksek olduğu görülmüştür $(P<0.05)$. Kontrol ve $D / 2$ dozları arasındaki farklılığın önemli olmadığı belirlenmiştir ( $P>0.05)$.

\section{Meyve Çapı (mm)}

Varyans analizi sonucunda mikoriza*doz interaksiyonunun istatistiki açıdan önemli olduğu görülmüştür $(\mathrm{P}<0.05)$. Mikoriza bulunan bitkilerde kontrol ile $D / 2$ arasında meyve çapı bakımından önemli bir fark bulunmazken $(P>0.05)$ kontrol grubundaki bitkilerin D, DX2 gruplarındaki bitkilerden daha düşük meyve çapına sahip olduğu görülmüştür $(P<0.05)$. Mikoriza bulunmayan bitkilerde ise kontrol grubunun meyve çapı, diğer gruplardan önemli derecede düşük bulunmuştur $(P<0.05)$. Ayrıca $D / 2, D$ ve $D x 2$ dozları arasında meyve çapı bakımından önemli bir fark belirlenememiştir ( $P>0.05)$. Meyve çapı kontrol grubunda, $D / 2$, D ve Dx2 dozunda mikorizalı>mikorizasız şeklindedir. Mikorizanın olup olmaması D/2, D, Dx2 dozlarındaki bitkileri meyve çapı bakımından etkilemezken ( $P>0.05)$, mikorizalı bitkilerin kontrol grubunun meyve çapı, mikorizasız bitkilerin kontrol grubunun meyve çapından daha yüksek bulunmuştur $(\mathrm{P}<0.05)$.

\section{Meyve Hacmi (ml)}

Meyve hacmine $(\mathrm{ml})$ ait tanıtıcı istatistik değerleri ve varyans analizi sonuçları Çizelge 4'de verilmiştir. Çizelge 4'e bakıldığında, varyans analizi sonucunda mikoriza*doz interaksiyonunun istatistiki olarak önemli olmadığı görülmektedir ( $P>0.05)$. Aynı şekilde pestisit dozları arasındaki farklılık da istatistiki açıdan önemli bulunmamıştır $(P>0.05)$. Mikorizalı meyve hacminin mikoriza olmadığında elde edilen meyve hacminden önemli derecede yüksek olduğu görülmektedir $(P<0.05)$. Meyve hacmi kontrol grubunda, $D / 2, D$ ve Dx2 dozunda mikorizalı>mikorizasız şeklindedir. Ayrıca en yüksek meyve hacmi ise mikorizalının $\mathrm{D} / 2$ dozu olarak bulunmuştur. 
Çizelge 3. Meyve çapına ( $\mathrm{mm}$ ) ait tanıtıcı istatistik değerleri ve varyans analizi sonuçları

\begin{tabular}{|c|c|c|c|c|c|c|c|c|c|c|c|c|c|c|c|}
\hline \multirow{2}{*}{$\begin{array}{l}\text { Fungusit } \\
\text { Dozu }\end{array}$} & \multicolumn{5}{|c|}{ Mikoriza Var $(n=3)$} & \multicolumn{5}{|c|}{ Mikoriza Yok (n=3) } & \multicolumn{5}{|c|}{ Genel $(n=6)$} \\
\hline & $\begin{array}{l}\text { Ort. } \\
(\bar{X})\end{array}$ & $\begin{array}{c}\text { Std } \\
\text { H. } \\
\left(S_{\bar{X}}\right)\end{array}$ & $\begin{array}{c}\text { Std. } \\
\text { S. } \\
\left(S_{X}\right)\end{array}$ & Min. & Max. & $\begin{array}{l}\text { Ort. } \\
(\bar{X})\end{array}$ & $\begin{array}{c}\text { Std } \\
\text { H. } \\
\left(S_{\bar{X}}\right.\end{array}$ & $\begin{array}{c}\text { Std. } \\
\text { S. } \\
\left(S_{X}\right)\end{array}$ & Min. & Max. & $\begin{array}{l}\text { Ort. } \\
(\bar{X})\end{array}$ & $\begin{array}{c}\text { Std } \\
\text { H. } \\
\left(S_{\bar{X}}\right)\end{array}$ & $\begin{array}{c}\text { Std. } \\
\text { S. } \\
\left(S_{X}\right)\end{array}$ & Min. & Max. \\
\hline Kontrol & 47.715Ba & 0.283 & 0.490 & 47.400 & 48.280 & $44.124 \mathrm{Bb}$ & 0.724 & 1.254 & 43.310 & 45.568 & 45.919 & 0.875 & 2.143 & 43.310 & 48.280 \\
\hline $\mathrm{D} / 2$ & 49.748ABa & 0.310 & 0.538 & 49.192 & 50.265 & 47.978Aa & 0.449 & 0.779 & 47.223 & 48.778 & 48.863 & 0.465 & 1.140 & 47.223 & 50.265 \\
\hline D & 50.967Aa & 0.487 & 0.843 & 50.140 & 51.825 & 50.328Aa & 0.360 & 0.623 & 49.800 & 51.015 & 50.648 & 0.306 & 0.750 & 49.800 & 51.825 \\
\hline DX2 & 50.757Aa & 0.568 & 0.984 & 49.912 & 51.837 & 49.974Aa & 0.798 & 1.383 & 48.392 & 50.947 & 50.366 & 0.472 & 1.156 & 48.392 & 51.837 \\
\hline $\begin{array}{l}\text { Genel } \\
(n=12)\end{array}$ & 49.797 & 0.429 & 1.486 & 47.400 & 51.837 & 48.101 & 0.788 & 2.728 & 43.310 & 51.015 & & & & & \\
\hline P-Değeri & & & & & & Mikoriza:C & ; Doz & $00 ; M$ & za*Doz & $47^{*}$ & & & & & \\
\hline
\end{tabular}

* istatistiki olarak önemlidir $(\mathrm{P}<0.05)$

Aynı sütunda, ortak büyük harfi olmayan ortalamalar arasındaki fark istatistiki olarak önemlidir $(P<0.05)$

Aynı satırda, ortak küçük harfi olmayan ortalamalar arasındaki fark istatistiki olarak önemlidir $(P<0.05)$

Çizelge 4. Meyve hacmine $(\mathrm{ml})$ ait tanıtıcı istatistik değerleri ve varyans analizi sonuçları

\begin{tabular}{|c|c|c|c|c|c|c|c|c|c|c|c|c|c|c|c|}
\hline \multirow[b]{2}{*}{$\begin{array}{l}\text { Fungusi } \\
\text { t Dozu }\end{array}$} & \multicolumn{5}{|c|}{ Mikoriza Var $(n=3)$} & \multicolumn{6}{|c|}{ Mikoriza Yok $(n=3)$} & \multicolumn{4}{|c|}{ Genel $(n=6)$} \\
\hline & $\begin{array}{l}\text { Ort. } \\
(\bar{X})\end{array}$ & $\begin{array}{l}\text { Std. } \\
\text { Hata } \\
\left(S_{\bar{X}}\right)\end{array}$ & $\begin{array}{l}\text { Std. } \\
\text { Sap } \\
\text { ma } \\
\left(S_{X}\right)\end{array}$ & Min. & Maks. & $\begin{array}{l}\text { Ort. } \\
(\bar{X})\end{array}$ & $\begin{array}{l}\text { Std. } \\
\text { Hata } \\
\left(S_{\bar{X}}\right)\end{array}$ & $\begin{array}{c}\text { Std. } \\
\text { Sapm } \\
\text { a } \\
\left(S_{X}\right)\end{array}$ & Min. & Maks. & $\begin{array}{l}\text { Ort. } \\
(\bar{X})\end{array}$ & $\begin{array}{l}\text { Std. } \\
\text { Hata } \\
\left(S_{\bar{X}}\right)\end{array}$ & $\begin{array}{c}\text { Std. } \\
\text { Sapma } \\
\left(S_{X}\right)\end{array}$ & Min. & Maks. \\
\hline Kontrol & 54.33 & 1.45 & 2.52 & 52.00 & 57.00 & 47.33 & 2.73 & 4.73 & 42.00 & 51.00 & 50.83 & 2.09 & 5.12 & 42.00 & 57.00 \\
\hline $\mathrm{D} / 2$ & 55.33 & 3.18 & 5.51 & 50.00 & 61.00 & 50.67 & 0.88 & 1.53 & 49.00 & 52.00 & 53.00 & 1.81 & 4.43 & 49.00 & 61.00 \\
\hline D & 51.67 & 1.20 & 2.08 & 50.00 & 54.00 & 49.00 & 1.53 & 2.65 & 47.00 & 52.00 & 50.33 & 1.05 & 2.58 & 47.00 & 54.00 \\
\hline $\mathrm{DX} 2$ & 52.33 & 2.85 & 4.93 & 49.00 & 58.00 & 50.00 & 1.16 & 2.00 & 48.00 & 52.00 & 51.17 & 1.47 & 3.60 & 48.00 & 58.00 \\
\hline $\begin{array}{l}\text { Genel } \\
(n=12)\end{array}$ & 53.42 & 1.09 & 3.78 & 49.00 & 61.00 & 49.25 & 0.83 & 2.86 & 42.00 & 52.00 & & & & & \\
\hline $\begin{array}{l}\text { P- } \\
\text { Değeri }\end{array}$ & \multicolumn{15}{|c|}{ Mikoriza:0.011* ; Doz:0.599 ; Mikoriza*Doz:0.655 } \\
\hline
\end{tabular}

*istatistiki olarak önemlidir $(\mathrm{P}<0.05)$

Fungusit Kalıntı Analizi Sonuçları

Domates meyvelerinde yapılan fungusit analiz sonuçları Çizelge 5'de belirtilmiştir. Analiz sonuçlarına örneklerin Çizelge 5. Fungusit kalıntı sonuçları çoğunun sayısal bir değeri olmadığı için istatistiki analiz yapılamamıştır.

\begin{tabular}{|c|c|c|c|c|c|}
\hline \multirow[t]{2}{*}{$\begin{array}{l}\text { Fungusit } \\
\text { dozu }\end{array}$} & \multicolumn{2}{|c|}{ Mikoriza var } & \multirow[t]{2}{*}{$\begin{array}{l}\text { Fungusit } \\
\text { dozu }\end{array}$} & \multicolumn{2}{|c|}{ Mikoriza yok } \\
\hline & $\mathrm{T} 1$ & $(-)$ & & T1 & $(-)$ \\
\hline \multirow[t]{3}{*}{ Kontrol } & $\mathrm{T} 2$ & $(-)$ & Kontrol & $\mathrm{T} 2$ & $(-)$ \\
\hline & T3 & $(-)$ & & T3 & $(-)$ \\
\hline & $\mathrm{T} 1$ & $(-)$ & & $\mathrm{T} 1$ & $(-)$ \\
\hline \multirow[t]{3}{*}{$D / 2$} & $\mathrm{~T} 2$ & $(-)$ & $\mathrm{D} / 2$ & $\mathrm{~T} 2$ & $(-)$ \\
\hline & T3 & $(-)$ & & T3 & $(-)$ \\
\hline & $\mathrm{T} 1$ & $(-)$ & & $\mathrm{T} 1$ & 0.082 (ölçüm limiti üzerinde) \\
\hline \multirow[t]{3}{*}{ D } & $\mathrm{T} 2$ & $(-)$ & $\mathrm{D}$ & $\mathrm{T} 2$ & $(-)$ \\
\hline & T3 & $(-)$ & & T3 & 0.050(ölçüm limitinde) \\
\hline & T1 & $(-)$ & & $\mathrm{T} 1$ & 0.065(ölçüm limiti üzerinde) \\
\hline \multirow[t]{2}{*}{ Dx2 } & $\mathrm{T} 2$ & $(-)$ & $\mathrm{D} \times 2$ & $\mathrm{~T} 2$ & $(-)$ \\
\hline & T3 & $(-)$ & & T3 & 0.070(ölçüm limiti üzerinde) \\
\hline
\end{tabular}




\section{Tartışma ve Sonuç}

Yapılan çalışmada mikorizalı ve mikorizasız ortamda büyütülen domates (Solanum lycopersicum L.) bitkilerine uygulanan farklı fungusit dozlarının domates meyvesi üzerindeki etkileri belirlenmeye çalışılmıştır. Çalışma sonucunda meyve ağırlığı, meyve boyu, meyve çapı ve meyve hacmi ölçüm sonuçları bütün pestisit dozlarında mikorizalı olanlarda istatistiki olarak önemli bulunmuştur ( $p<0.05$, Çizelge1, 2, 3, 4). Özellikle mikorizalı bitkilerin kontrol grubunun meyve ağırlığı, çapı ve hacmi mikorizasız olan bitkilerin kontrol grubunun meyve çapından daha yüksek bulunmuştur $(\mathrm{P}<0.05)$. Ancak mevcut çalışmada ölçümleri yapılan meyveler pestisit analizine gönderilmesi için hasat edildiğinden büyümeleri ve renklenmeleri tamamlanamadığı için literatürde belirtilen değerlerden boy, ağırlık ve hacim olarak daha küçüktürler (Ünlü ve Padem, 2009). Bununla beraber literatürde meyvelerin olgunlaşmadan önce de fiziksel özelliklerinin belirlenebileceği belirtilmiştir (Bostan ve Günay, 2014).

Yapılan bu çalışmada özellikle kontrol grubuna göre meyve ağırlığı, meyve boyu, meyve çapı ve meyve hacmi ölçüm parametrelerinde artış görülmesi anlamlıdır. Cucumis sativus L. (hıyar) bitkisinin verim ve kalitesi üzerine bazı aktivatör ve fungusit uygulamalarının etkilerinin incelendiği bir çalışmada da bizim çalışmamıza benzer sonuçlar tespit edilmiştir (Dereboylu ve Tort, 2010). Yapılan başka bir araştırmada, sera şartlarında yetiştirilen biber bitkisine 14 gün arayla üç kez harpin proteini (aktivatör) uygulanarak sonuçları incelenmiştir. Araştırma sonucunda aktivatör uygulamasının biber bitkilerinde toplam verimi arttırdığı bildirilmiştir (Akbudak ve ark., 2004). Tarım ürünlerinde görülen hastalıkların azaltılması için bitki aktivatör proteinlerinin kullanıldığı bir çalışmada, üç farklı domates ile iki farklı kanola çeşidinde kullanılan aktivatörlerin erken yaprak yanıklığı hastalığını azalttıkları, kontrol grubuna göre verimi \% 10-13 oranında arttırdıkları tespit edilmiştir (Tort ve ark., 2004). Pestisit uygulamaları ile birlikte kullanılan biyolojik tabanlı bitki aktivatörlerinin bitki biyokütlesinin, meyve boyutlarının, kalitesinin, ürün veriminin ve stres toleransının artmasına neden olduğu rapor edilmiştir (Copping, 2000).

Bitkisel üretimde kayıplara neden olan hastalık, zararlı ve yabancı otlarla mücadelede pestisitlerin yaygın olarak kullanıldığı bilinmektedir (Yeşil ve Ögür, 2011). Pestisitlerin kullanılmadığı durumlarda ürünlerde kalite ve verim düşüklüğü olmasından dolayı ülkemizde de tüm dünyada olduğu gibi bitki koruma ürünlerinin kullanılmasının kaçınılmaz olduğu ifade edilmektedir (Tiryaki ve ark., 2010). Pestisitlerin aşırı ve bilinçsiz kullanımı çevre kirliliği ve insan sağlığı açısından ciddi sorunlar ortaya çıkarmaktadır. Üreticilerimizin pestisitleri önerilen dozun dışında bilinçsiz kullanımları ürünlerde kalıntı problemlerine neden olabilmektedir. Bu ürünlerdeki kalıntılar dış ticarette önem taşımaktadır. (Yeşil ve Ögür, 2011). Bu düşüncelerle kurguladığımız çalışmamızın pestisit kalıntı sonuçlarına bakıldığında; mikoriza bulunan bitkilerin meyvelerinde pestisit uygulanan dozların hiçbirinde pestisit kalıntısına rastlanmamıştır. Mikorizasız bitkilerin meyvelerinde $D / 2$ dozunda pestisit kalıntısına rastlanmazken, $D$ ve $D \times 2$ dozlarında ölçüm limitinde ve ölçüm limitinin üzerinde pestisit kalıntısına rastlanmıştır.

Seralarda yetiştirilen sebzelerde kullanılan ilaç kalıntılarının ülkemizdeki boyutunu belirlemek için seracılığın en yoğun olduğu Antalya, Mersin, Adana ve Muğla illerindeki sera, tarla, bahçe ve satış noktalarından yıl boyunca alınan örnekler analiz edilmiştir. Analizlerde çoklu kalıntı analiz metotları kullanılarak; sebze, meyve, bağ, vb. ürünlerde tavsiyesi olan ve az da olsa tavsiye dışı kullanımı olan etkili maddeler aranmıştır. Toplam 1.532 adet sebze ve meyve örneğinin analizi sonucunda örneklerin 23 adedinde tolerans değerlerinin üzerinde, 109 adedinde tolerans değerlerinin altında ilaç kalıntısı tespit edilmiştir. 1.400 adet örnekte ise tespit edilebilir seviyede kalıntıya rastlanmamıştır. Limitin üzerinde kalıntı tespit edilen örnek oranı \% 1.5 olarak belirlenmiştir (Durmuşoğlu ve Çelik, 2001). Ülkemizde kalıntı düzeylerinin tespiti amacıyla 19962000 yılları arasında gerçekleştirilen bir proje kapsamında, serada yetiştirilen domates, hıyar ve biber örneklerinde malathion, diazinon, methylparathion, dichlorvos (DDVP), bromoproplate, endosülfan kalıntıları taranmış ve limit üstü değere rastlanmamıştır. Aynı araştırıcılar, 2001/2002 yıllarında geniş bir sebze ve meyve grubunda pestisit taraması yapmışlar ve alınan örnekler içinde sadece bir grup domateste $0.16 \mathrm{ppm}$ procymidon bulunduğunu belirtmişlerdir (Gazozcuzade, 2010). Tiryaki (2016) tarafından ülkemizde yapılan pestisit kalıntı çalışmaları derlenmiştir. Çalışmada 26 tane derleme, 50 tane orijinal makale çalışması incelenerek pestisit kalıntı analizleriyle ilgili çalışmaların öneminden bahsedilmiştir.

Mevcut çalışmada, mikorizalı bitkilerde pestisit kalıntısına rastlanmamışken. mikorizasız bitkilerde D ve DX2 dozlarında belirlenen pestisit kalıntı miktarları dikkat çekici bulunmuştur. AMF(Arbüsküler Mikorizal Fungus) lar enfekte ettikleri bitkinin büyüme ve gelişmesine katkı sağlaması yanında bitkilere çeşitli biyotik ve abiyotik faktörlere karşı tolerans, dayanıklılık gibi avantajlar da sağlamaktadırlar (Zhu ve ark., 2010). Ayrıca, mikorizal oluşumlar bitki hastalıklarının biyolojik mücadelesinde ve bitkilerin büyüyüp gelişmesinde önemli rol oynarlar. Yaptığımız çalışmada kullanılan fungusitin mikoriza ile enfekte olmuş domateslerde pestisit kalıntısına rastlanılmamış olması mikorizaların fungusitin bitki bünyesine geçmesinde bir bariyer olabileceğini gösterebilir. AMF (Arbüsküler Mikorizal Fungus) bitki korumada ve hastalıklarda yüksek başarı gösteren bir mikoriza grubudur. AMF ve biyolojik mücadele elemanları arasında sinerji olduğu kanıtlanmıştır. Bu interaksiyonlar bitkilerde kök salgıları, fitoaleksinler ve fenolik bileşiklerin üretimini teşvik etmektedir. Böylece, AMF bitki ve toprak mikrobiyal aktivitesini etkilemektedir. Ayrıca mikoriza faaliyeti esnasında kitinaz, glukanaz, flavonoid biyosentezi ve fitoaleksinlerin üretimi için özellikle bitki savunma genlerinin aktivitesinde az da olsa bir artış olduğu belirlenmiştir (Biçici, 2011). 
Bitki hastalıklarıyla mücadelede kimyasal mücadeleye alternatif biyolojik mücadelenin yaygınlaşması ve mikorizal uygulamaların önemi her geçen artmaktadır. Bu nedenle özellikle son yıllarda bitki hastalıklarıyla biyolojik mücadelede kullanılmak üzere mikorizal mantarlarla hazırlanmış olan tarım ilaçları piyasaya çıkmıştır. Bununla beraber, mikorizal fungusların tüm hastalıklar için kullanılabilecek bir ürün olmadığını bilmek gerekmektedir. Ayrıca, biyolojik mücadelenin ekolojik olarak zaman alacağı, patojen ve hastalığı tamamen ortadan kaldırma yerine onu baskılayabilme yönünde iş görebileceği ve daha çok hastalıklardan korunma şeklinde başarı sağlanabileceği unutulmamalıdır. Mikorizal funguslar uygulanırken, patojen mikroorganizma hastalık yapmadan önce; bizim çalışmamızda olduğu gibi ekim, dikim döneminde tohuma, toprağa veya fideye uygulama yapılması gerekmektedir (Biçici, 2011). Ekosistemin bir parçası olan mikorizanın etkinliği; bitki hastalık ve zararlılarına karşı mücadelede kullanılması, bitki için gerekli bitki besin elementlerinin alımını arttırması, bitki gelişimini ve verimini çoğaltan olumlu etkileri bilimsel çalışmalarla ortaya konulmakta ve her geçen gün mikorizal fungusların önemi ve tarımsal üretimde kullanım alanları giderek artmaktadır (Almaca, 2014).

Günümüzde tarımsal alanlarda yaygın bir şekilde kullanılan pestisitlerin canlı ve çevre sağlığına olan zararları bilimsel olarak kanıtlanmıştır. Bakteriyel ve fungal hastalıkların zararlarını önlemede kullanılan pestisitler ile ilgili en büyük sorun bilinçsiz ve kontrolsüz kullanımdır. Bilinçsiz kullanım bu ilaçların doğada ve canlıda birikmesine neden olmaktadır. Bu nedenle besin zinciri yoluyla insana kadar ulaşan bu tehlikeli maddelerin zararlarını minimuma indirecek yöntemler ya da bunlara alternatif uygulamalar geliştirmek zorundayız. Alternatif yöntemlerin seçiminde ise doğanın içinde olan, kendisine yabancı olmayan ekolojik olarak işlevsel model veya örneklerin kullanılmasına dikkat edilmesi gerekmektedir.

Mevcut çalışmada mikorizanın pestisit uygulamalarındaki etkisi domates meyve parametreleri üzerinde incelenmeye çalışılmıştır. Bu çalışmada doğada yaygın olarak bulunan, çeşitli stres faktörlerine karşı bitkiye direnç sağlayan faydalı mikorizal fungusların pestisitlere karşı da dayanıklılık gösterebileceği düşünülmüştür. Yapılan çalışma sonucunda meyve parametreleri üzerindeki karşılaştırmalı ölçümler pestisit uygulamalarına rağmen meyve üzerinde mikorizanın olumlu sonuçları olduğunu göstermiştir. Özellikle elde edilen üründe (domateste) pestisit kalıntısına rastlanılmamış olması mikorizanın pestisite karşı bitkiye dayanıklılık sağladığının bir göstergesi olabilir. Çalışmadan elde edilen bu umutvari sonuçların bu konuda ileride yapılabilecek daha kapsamlı çalışmalara ve literatüre ışık tutacağı kanısındayız.

\section{TEŞEKKÜR}

Bu çalışma Ordu Üniversitesi Bilimsel Araştırma Projeleri Koordinasyon Birimi AR-1535 no'lu projenin bir kısmıdır. Katkılarından dolayı teşekkür ederiz.

\section{KAYNAKLAR}

Abdulhadi S, Saymen M, Türkmen Ö (2017) Tuzlu Toprak Koşullarında Kabakta Arbusküler Mikorhizal Fungus Uygulamalarının Fide Gelişmesine Etkisi. Manas Journal of Agriculture Veterinary and Life Science 7 (2): 1-12.

Akbudak N, Şeniz V, Tezcan H (2004) Effect of harpin protein on yield and fruit quality of pepper grown in greenhouse conditions. III. Balkan Symposium on Vegetables and Potatoes (6-10 Eylül 2004, Bursa) 267-270.

Azimi R, Heshmati GA, Kianian MK (2018) Effects of Drought Stress and Mycorrhiza on Viability and Vegetative Growth Characteristics of Ziziphora clinopodioides Lam. Journal of Rangeland Science Vol. 8, No. 3.

Altuntaş Ö, Abak K, Yıldız Daşgan, H (2015) Serada Biber Yetiştiriciliğinde Arbusküler Mikorhizal Fungus Kullanımının Bitki Gelişimi ve Verime Etkileri. Selçuk Tar Bil Der 2(2): 144-151.

Almaca A (2014) Tarımsal üretimde mikorizanın önemi. Harran Tarım ve Gıda Bilimleri Dergisi 18 (2): 58-67.

Battke F, Schramel P, Ernst D (2003) A novel method for in vitro culture of plants:cultivation of barky in a floating hydroponic system. Plant Molecular Biology Reporter 21 (4): 405-409.

Biçici M (2011) Bitki hastalık etmenleri ile biyolojik mücadelenin başarısını arttırmada mikorizanın rolü. Türkiye biyolojik mücadele dergisi 2 (2): 139-174.

Bostan Z, Günay K (2014) Hayward' (Actinidia deliciosa Planch) kivi çeşidinin meyve kalitesi üzerine rakım ve yöneyin etkisi. Akademik Ziraat Dergisi 3 (1): 13-22.

Chhabra ML, Jalali BL (2013) Impact of pesticidesmycorrhia interaction on growth and development of wheat. Biopest 6(2): 129-132.

Copping LG, Menn JJ (2000) Biopesticides: a review of their action, applications and efficacy. Pest Management Science 56 (8): 651-676.

Delen N, Kınay $P$, Yıldız F, Yıldız M, Altınok HH, Uçkun Z (2010) Türkiye tarımında kimyasal savaşın durumu ve entegre savaşım olanakları. Türkiye Ziraat Mühendisliği VII. Teknik Kongresi (11-15 Ocak 2010, Ankara) 609-625.

Dereboylu AE, Tort N (2010) Bazı aktivatör ve fungisit uygulamalarının Cucumis sativus L. (hıyar) bitkisinde verim-kalite üzerine etkisi. Cumhuriyet Üniversitesi Fen Edebiyat Fakültesi Fen Bilimleri Dergisi 31 (1): 3042.

Durmuşoğlu E, Çelik C (2001) Türkiye'de pestisit kalıntıları üzerinde yapılan çalışmalar. Türkiye Entomoloji dergisi 25 (1): 65-80.

Erzurumlu GS, Kara EE (2014) Mikoriza konusunda Türkiye'de yapılan çalışmalar. Türk Bilimsel Derlemeler Dergisi 7 (2): 55-65.

Gazozcuzade N (2010) Silifke Yayla Köylerinde Domates Üretiminde Hastalık Yönetimi, Çukurova Üniversitesi Fen Bilimleri Enstitüsü (Basılmamış) Yüksek lisans tezi Adana, $83 \mathrm{~s}$. 
Marin M, Ybarra M, Fe A, Garcia-Ferriz L (2002) Effect of arbuscular mycorrhizal fungi and pesticides on Cynara cardunculus growth.Agricultural and Food Science in Finland (11):245-251.

Naomi L, Rintoul J (2016) Arbuscular mycorrhizal associations in plant nutrition and health. CAB Reviews, 11 (17). pp. 1-16. ISSN 17498848.

Rafique M, Ortaş i (2018) Nutrient uptake-modification of different plant species in Mediterranean climate by arbuscular mycorrhizal fungi. European Journal of. Horticulture Science 83(2), 65-71.

Palta Ş, Demir S, Şengönül K, Kara Ö, Şensoy GH (2010) Arbüsküler Mıkorızal Funguslar (Amf), Bitki Ve Toprakla İlişkileri, Mera Islahındaki Önemleri. Bartın Orman Fakültesi Dergisi, Cilt: 12 Sayı: 18, 87-98.

Palta Ş, Genç Lermi A, Beki R (2016) The effect of different land uses on arbuscular mycorrhizal fungi in the northwestern Black Sea Region. Environ Monit Assess 188: 350

Ted J (2002) Mycorrhizae and Plant Community. http:// mycorrhiza.org. (Erişim tarihi: 24.04.2019).

Tilak KVBR, Ranganayaki N, Pal KK, De R, Saxena AK, Nautiyal CS, Mittal S, Tripathi AK, Johri BN (2005) Diversity of plant growth and soil health supporting bacteria. Current Science 89 (1):136-150.
Tiryaki O, Canhilal R, Horuz S (2010) Tarım ilaçları kullanımı ve riskleri. Erciyes Üniversitesi Fen Bilimleri Enstitüsü Dergisi 26(2): 154-169.

Tiryaki O (2016) Türkiye'de yapılan pestisit kalıntı analiz ve çalışmaları. Erciyes Üniversitesi Fen Bilimleri Enstitüsü Dergisi 32(1): 72-82.

Tort N, Öztürk I, Tosun N (2004) Fungisit uygulamalarının domates (Lycopersicon esculentum Mill.)'in anatomik yapısı ve fizyolojisi üzerine etkisi. Ege Üniversitesi Ziraat Fakültesi Dergisi 41 (2): 111-122.

Tort N, Türkyılmaz B, Dereboylu AE, Tosun N(2004) Diniconazole etken maddeli bir fungisitin bazı arpa kültür formları üzerine morfolojik ve fizyolojik etkileri. Ege Üniversitesi Ziraat Fakültesi Dergisi 41(1): 169179.

Ünlü H, Padem H (2009) Organik domates yetiştiriciliğinde çiftlik gübresi, mikrobiyal gübre ve bitki aktivatörü kullanımının verim ve kalite özellikleri üzerine etkileri. Ekoloji 19 (73): 1-9.

Yeşil S, Öğür E (2011) Zirai mücadelede pestisit kullanımının Türkiye'de ve Konya ölçeğinde değerlendirilmesi ve pestisit kullanımının olası sakıncaları. I. Konya Kent Sempozyumu, (26-27 Kasım 2011, Konya 439-449 s.

Zhu X, Song F, Xu H (2010) Influence of arbuscular mycorrhiza on lipid peroxidation and antioxidant enzyme activity of maize plants under temperature stress. Mycorrhiza 20:325-332. 